Island Studies Journal, Vol.7, No. 1, 2012, pp. 19-48

\title{
Of Hubs and Hinterlands: Cyprus as an Insular Space of Overlapping Diasporas
}

\author{
Janine Teerling \\ Sussex Centre for Migration Research \\ University of Sussex \\ United Kingdom \\ J.C.J.Teerling@sussex.ac.uk
}

and

\author{
Russell King \\ Sussex Centre for Migration Research \\ University of Sussex \\ United Kingdom \\ R.King@sussex.ac.uk
}

\begin{abstract}
This paper uses the metaphor of diasporic hubs and hinterlands to document and analyse the various diasporic formations that overlap and encounter each other on the divided island of Cyprus. After a review of the various ways that islands interface with migration processes and some essential historical and statistical background on Cyprus and its population, the paper considers a number of migrations/diasporas that are based on or affect the island. They include the emigration from the diasporic hub of Cyprus during the 1950s-1970s; return migration, both of the original emigrants and their descendants; the British military/colonial settlement of Cyprus; retirees and 'lifestyle migrants'; and various categories of recent immigrants, for whom Cyprus is a diasporic hinterland. We draw both similarities and differences between migratory dynamics in the northern, Turkish Cypriot part of the island and the southern, Greek Cypriot part. In the final part of the paper we describe recent fieldwork on various spaces of inter-diasporic encounter in Cyprus.
\end{abstract}

Keywords: Cyprus; diaspora; inter-migrant encounter; migration; partition; return migration.

(C) 2012 Institute of Island Studies, University of Prince Edward Island, Canada

\section{Introduction}

Fifty years ago, Lowenthal and Comitas (1962) wrote an intriguing paper in the Geographical Review on 'neglected aspects' of emigration and depopulation within the field of population geography. They used the Greek island of Ithaca and the Caribbean island of Montserrat to illustrate their arguments, which were, essentially, that islands, especially small islands, are destined to become fountain-heads of emigration due to population growth and the pressure of population density on a narrow resource base. As a result, they said, a 'metamorphosis' takes place from a 'peasant society' to a 'remittance society' (1962: 204). Rapid depopulation ensues (Ithaca's population halved from 11,409 in 1896, to 5,877 in 1951), the self-sufficient rural economy collapses, yet the general level of material well-being does not diminish; rather it goes up. To a large extent, it is the 'remittance society', and the 'culture of emigration' of the 


\section{J. Teerling \& R. King}

islanders, that explain this fundamental change in insular economies and demography. As Lowenthal \& Comitas wrote: 'Emigration, which began as a result of a particular set of circumstances at a specific point in history, has become an integral part of the social process and an essential in the satisfaction of personal and familial expectations' (1962: 205).

The above vignette, drawn from descriptive human geography of an earlier generation of scholars, presents a somewhat essentialized picture of the relationship between islands and migration: that emigration, depopulation, and survival only through the welfare support of remittances, is destiny. In actual fact, not much has changed with regard to these two islands' downward population trend since these authors wrote their paper. Ithaca's population has continued to decline, to 3,178 in 2011 (www.ithaki.gr). Montserrat was devastated by volcanic eruptions which lasted from 1995 to 1997, smothering half of the island and causing major population displacements. The population of the island dropped from 11,000 to 4,922 in 2011 (www.gov.ms/?p=6257).

The association between small islands and depopulation has certainly been confirmed in various other insular settings around the world, but also modified by other island-migration relationships. By no means have all islands, even small ones, been 'marginal spaces' destined to depopulate; others have been 'nodes' which have consistently attracted people due to their strategic location in terms of the 'spaces and flows' of the global economy and changing geopolitics (King, 2009; King \& Kolodny, 2001). In fact, especially for somewhat larger islands such as Cyprus, the links between insularity and migration become ever more complex, due to the increasing dynamism and fluidity of migration processes in the current era of globalization. Our purpose in this paper is to explore further these evolving relationships, based on a case study of Cyprus, the Mediterranean's third largest island in terms of population size (after Sicily and Sardinia). As well as discussing migrations from, to, and within Cyprus, we also use a 'diaspora lens' to draw contrasts between historical migration waves that have Cyprus as their 'hub' (the Cypriot diaspora itself) and other migrations and diasporas which have their hubs elsewhere but which incorporate Cyprus as part of their 'hinterland' (notably the British colonial/military diaspora but also more recent in-migrations) ${ }^{1}$.

\section{Islands, Migrations and Diasporas}

The notion of islands as multi-diasporic spaces of intersecting migrations derives from new thinking about the nature of migration and mobility, and of different diasporic formations, above all linked to the strategic roles that islands play nowadays in the geopolitics of migration and their attractiveness to tourists and 'lifestyle migrants' (a term we shall define presently). Let us unpack and exemplify this statement. We make three key points: about the geopolitical categorization of islands; about the diversity of migratory forms; and about islands as spatial settings for inter-migrant encounters.

Administratively and geopolitically, we can distinguish three types of island status. First are islands which 'belong' to a larger 'mainland' country and to which they often have a peripheral relationship: for instance, the Azores to Portugal or Corsica to France. However, if these

\footnotetext{
${ }^{1}$ The 'hubs and hinterlands' terminology comes from Binod Khadria's presentation at the 2011 Metropolis conference: see Khadria (2011).
} 
'peripheral' islands are close to another country, and especially if they are close to a migrantsupply area or route, then they acquire renewed geo-strategic significance as stepping-stones or entry-points for migrants seeking to move from high 'migrant pressure' sources to desirable but difficult-to-access destinations. Within the broad scenario of migration from North and West Africa to Europe, the two most obvious cases have been the Canary Islands and Lampedusa, European Union (EU) islands located close to the African shore.

Second, there are islands which are sovereign states. Such island-states have autonomous control over their in and out migration flows, as least theoretically. But again geographical proximity to a major migrant source area may put enormous pressure on the ability of the island to manage such flows without outside help. The case of Malta is emblematic of this situation (King, 2009: 69-75).

The third geopolitical situation is much rarer: islands which are divided into two (or more) states. Cyprus is a case in point, although obviously there are different interpretations as to the legitimacy of the North Cyprus breakaway state (King \& Ladbury, 1982). Cyprus apart, the classic example is the Dominican Republic and Haiti which share the Caribbean island of Hispaniola. The point here is that division sets up migration pressures between the two constituent territories, especially if there are differences in income and employment opportunities. This is certainly the case between North and South Cyprus, and between very poor Haiti and the not-so-poor Dominican Republic.

Our second key point is about the diversification of types of migration and mobility. Migration is driven nowadays by multiple forces and triggers, and expresses itself in a range of outcomes, differentiated by motivation, length of stay, likelihood of future return, and many other variations. Many scholars prefer to speak of 'mobilities' rather than migration (Adey, 2010; Urry, 2007). This reflects the blurring of the divide between the two occasioned by seasonal and temporary moves, by business stays, by students studying abroad, by residence-based tourism, and by refugee-like situations in which people fleeing crises of various kinds may move from one place to another. Cyprus provides a suitable setting to study these migration and mobility types. This leads to our third key point.

The final element has to do with the special character of islands as micro-laboratories for the study of diverse migration processes and their various interactions (Connell, 2007; Connell \& King, 1999). We argue that an (especially small) island, with its small towns and more 'intimate' spaces, creates a more fertile setting for inter-ethnic encounters. Later on in this article, we will illustrate how new cultural spaces of belonging have emerged through the everyday encounters which take place within the spatially reduced island setting between various migrant, expatriate, returnee and native groups. These new spaces of inter-ethnic and intercultural encounter raise important questions about ongoing global and local social transformations, and perhaps call for a new focus on alternatives to so-called 'ethnic enclaves' on the one hand and cultural 'clashes' or disjunctures between 'immigrants' or 'outsiders' and 'natives' on the other.

From these histories and typologies of multiple migrations and mobilities, and from Avtar Brah's concept of 'diaspora space' (1996), we derive our hypothesis of Cyprus as a 'multidiasporic space' (Teerling \& King, 2011) made up of overlapping diasporas and their everyday 


\section{J. Teerling \& R. King}

intercultural encounters. Unlike the rather placeless transnational fields which, while established by definition across national borders, are often based on, and maintain, common cultural and ethno-national features, the multi-diasporic spaces proposed here are geographically localized within the island, and often within particular micro-spaces of personal encounter.

\section{Cyprus: Some Background}

In order to appreciate the complex migration realities of Cyprus, a 'divided island' since 1974, we need to sketch some essential history. Following three centuries of Ottoman rule, the British colonial period lasted from 1878 until 1960, and was succeeded by a rising tide of interethnic conflict between Greek and Turkish Cypriots. The former contained active elements who wanted enosis or union with Greece. The Turkish Cypriots were horrified at this prospect and subsequently favoured taksim, the division of the island into two sectors. The 1960 constitution aimed at safeguarding the interests of the minority Turkish Cypriots (who made up $18 \%$ of the total population) against the majority Greek Cypriots, but failed to prevent an upwelling of ethnic discord as both groups strove to pursue their respective political objectives. During four years of inter-communal strife, 1963-67, the Turkish Cypriots retreated into a number of scattered enclaves under a provisional Turkish-Cypriot administration (Papadakis, 1998; Papadakis et al., 2006; Patrick, 1976).

Although the Greek Cypriot leadership under Archbishop Makarios started to distance itself from the aim of union with Greece, the situation changed dramatically when the Greek junta took power in Athens and deposed Makarios in July 1974, paving the way for enosis. Almost immediately, Turkey intervened militarily, occupying the northern sector of the island. Greek Cypriots fled from the occupied north to the safety of the south, thinking their displacement would be temporary. The Turkish army, however, consolidated its hold over the north, which became the destination for Turkish Cypriots transferred from the south. Almost one-third of the population of Cyprus was displaced as a result of this forced population exchange (Loizos, 1981). The island has since been partitioned between the Republic of Cyprus (ROC) in the south and the self-declared Turkish Republic of Northern Cyprus (TRNC), recognized only by Turkey, in the north. A United Nations-managed 'Green Line' separates the two sectors, which for three decades were effectively sealed off from one another. Recent years, however, have seen some renewed contact and movement across the 1974 frontier.

Repeated attempts have been made to resolve the 'Cyprus problem', especially in light of Cyprus' accession to the EU in 2004, but the fundamental impasse remains. Although the general principle of a bizonal federated state seems to have fairly wide support, also amongst important sections of the international community, progress has been slow. The Turkish Cypriots fear being swallowed up by the majority Greeks, who aspire to return as much as possible to the status quo ante, and reclaim and resettle their 'stolen property' in the north. Meanwhile, different systems of migration have developed north and south of the Green Line. Especially in the south, and ignoring the intra-island migrations and displacements, Cyprus has experienced the kind of migration 'reversal' or 'turnaround' typical of other Southern EU countries such as Greece, Italy, Spain and Portugal, transforming itself from a country which, in the early postwar decades, 'exported people', into a society which hosts migrants from many different countries (King et al., 1997). 
Today, 'Greek' Cyprus has a large and highly diverse immigrant population from different parts of Europe, the Middle East, Africa, and South and East Asia. They comprise retirees, expats, entrepreneurs, professionals, male labour-migrants, female domestic workers, and 'entertainers' and sex workers. Return migration of Cypriots from the diaspora has also been ongoing since the 1970s. Those who have returned in more recent years find a 'homeland' which has changed from a largely rural society at the time of their departure to a modernized, post-industrial, service and tourism-dominated economy (King \& Thomson, 2008; Trimikliniotis, 2008). Somewhat different migration dynamics have evolved post-1974 in northern Cyprus and these will be dealt with later in the paper.

\section{Migration Facts and Figures}

Recent data from the World Bank and Eurostat reveal some intriguing features of the migration trends in Cyprus. First, the 'stock' of emigrants, 149,600 in 2010, equivalent to $17 \%$ of the resident population of just over 900,000, is very similar to the 'stock' of immigrants, 154,300 or $17.5 \%$ of the population (World Bank, 2011: 102). These two flows, out and in, have not taken place simultaneously, with the bulk of emigrations preceding immigration, giving rise to the aforementioned 'migration turnaround'. One perplexity not clarified by the World Bank statistics is whether the data includes figures for the TRNC. Probably they do for emigration since most of this occurred before 1974, and Turkey is listed amongst the top ten destinations ${ }^{2}$. Probably they do not for immigration, since most of this is post-partition, and Turks (known to be numerous as settlers in the TRNC) are not amongst the top ten source countries ${ }^{3}$.

A second set of migration statistics, this time on flows, comes from EU data summarized by van Nimwegen \& van der Erf $(2010: 1361,1370)$. Of the EU27, Cyprus had the highest rate of immigration, proportionate to its population, during the mid-to-late 2000s. This statistical fact is all the more remarkable given that Cyprus also had the highest rate of emigration of all EU countries over the same period. Cyprus also ranks high on two other indicators of immigration: population with foreign citizenship (second, after Luxembourg) and population of foreign birth (third, after Luxembourg and Ireland) ${ }^{4}$.

We now move into the heart of the paper, which describes the various diasporas and migrations which intersect the partitioned island of Cyprus. This draws on a substantial and long-term research engagement with the island, starting with early work on the political geography of partition (King \& Ladbury, 1982), and moving on to more recent field research on 'counterdiasporic' or 'return' migration of British-born Cypriots (Teerling, 2011a; 2011b), including childhood return visits (King et al., 2011). The final section of the paper presents ongoing fieldwork on inter-migrant encounters in various island spaces.

\footnotetext{
${ }^{2}$ In rank order: the UK, Australia, Greece, Turkey, US, Canada, Germany, France, Jordan, and Sweden.

${ }^{3}$ In rank order: UK, Greece, Georgia, Russia, Sri Lanka, Philippines, Bulgaria, Romania, Egypt and South Africa.

${ }^{4}$ In the graphs which list countries according to the percentage of population with foreign citizenship or foreign birth (van Nimwegen \& van der Erf, 2010: 1372, 1375), Estonia and Latvia also rank high (between Luxembourg and Cyprus), but we discount these cases because nearly all 'foreign' citizens or births are Russians who migrated 'internally' and settled in these two countries during the Soviet era.
} 


\section{Emigration from Cyprus and the Formation of the Cypriot Diaspora}

Emigration from Cyprus was concentrated in the early postwar decades. It was primarily economically motivated: a reaction against poverty, especially in rural areas. But it took place against a political landscape that was shifting in two dimensions. First, there was the decolonization process, leading to Cypriot independence in 1960. Second were the inter-ethnic conflicts within Cyprus between the numerically and economically dominant Greek Cypriots and the less numerous and generally poorer Turkish Cypriots.

Cypriot emigration was directed mainly to the UK, and especially London. Even so, some Cypriots settled in such Commonwealth or Anglophone destinations as Australia, Canada, US and South Africa. Moreover, some Greek Cypriot migration headed to Greece, and Turkish Cypriot to Turkey; such moves were often related to higher education and career opportunities. Taken in the round, by the 1980s, the estimated number of Cypriots living abroad (migrants and their descendants - the Cypriot diaspora) was half of the island's population (Anthias, 1992; Trimikliniotis \& Demetriou, 2007; see Robins \& Aksoy, 2001 for Turkish Cypriots).

The UK was the preferred choice for various reasons, largely to do with the strength of its economy and demand for labour in the early postwar decades, but also because, as the colonial power, it had heavily influenced language and education in Cyprus. At the time that the UK economy was booming, Cyprus was entering a phase of political uncertainty and economic deprivation. The majority of Cypriot emigrants in the UK at this time came from rural backgrounds. The rural economy had stagnated due to the failure of the colonial government to provide resources for agricultural modernization. Land was intensely fragmented and rural families were generally large. However, the government's support of local industrial development failed too; hence the high levels of unemployment in towns encouraged urban Cypriots also to emigrate (Anthias, 1992). A further wave of emigration took place after the 1974 partition, especially of Greek Cypriots displaced from the north.

The temporal development of Cypriot emigration closely reflects these political and economic factors. Throughout the early 1950s, when emigration and employment opportunities in Britain and elsewhere started to open up for Cypriots, annual departures were in the range of 3,000 to 5,000 . The flow then swelled in the late 1950s reaching peaks of around 14,000 in 1960 and 1961, after which the Commonwealth Immigration Act (1962) caused the rate to drop back sharply to around 2,000-3,000 per year for the rest of the 1960s. A new pulse of emigration occurred in the wake of partition, rising to over 5,000 in 1975-1976, falling back to a few hundred per year in the early 1980s (Constantinou, 1990: 146). During this period, the Turkish Cypriots' share of Cypriot emigration roughly matched their share of the Cypriot population: about one-fifth (Hatay, 2007: Appendix 3).

British census data charts a build-up of the Cypriot immigrant community in Britain, but only on the criterion of birthplace. By 1991, 78,191 Cypriot-born are recorded, down slightly to 77,156 in 2001 , due to deaths among an ageing first generation and some return migration. The 'second generation', British-born, is excluded from the census figures, and no distinction is made between Greek and Turkish ethnicity. Estimates of the total Cypriot community range from lows of 100,000-220,000 (Anthias, 1992; Oakley, 1979) to highs of 250,000-300,000 (Papapavlou \& Pavlou, 2001). 
In the UK, and especially in London where the bulk of the UK-based Cypriots settled, job opportunities were mainly at the lower echelons of the labour market: as usually happens for labour migrants arriving from less-developed areas with limited human capital. Many were initially involved in the catering business, working long hours as kitchen staff and waiters in restaurants and hotels. Others deployed skills traditionally used in Cyprus, such as tailoring and dressmaking, and became economically active in the clothing industry: the 'rag trade'.

Rather quickly, many Cypriots used their savings and commitment to hard work to set up family businesses: cafés, restaurants, small clothing firms and workshops. The 1971 census recorded a level of self-employment amongst Cypriots (23\%) which was well in excess of the national average (9\%) (Anthias, 1992: 53-54). In her 1977 study of the Greek Cypriot community in London, Pamela Constantinides stressed the variety of jobs Cypriots were willing to undertake, usually leading to a career in small business: 'cake shops, travel agencies, dress shops, furniture stores, television and radio repair shops, butchers, builders, hairdressers, grocers and greengrocers, fish and chip shops, bakeries, dry-cleaners, mini-cab offices and estate agents' (1977: 280). She also emphasized the strength and coherence of the Cypriot 'ethnic economy', based on ethnic solidarity and strong family and kinship structures rooted in the characteristics of Cypriot village society.

To some extent, ethnic solidarity was maintained across the Greek-Turkish Cypriot 'divide': despite different languages and religions, there was a shared sense of Cypriotness, and a shared experience of having lived on an island subject to British colonialism. In London and elsewhere, Greek and Turkish Cypriots employed each other, rented accommodation to each other, but rarely intermarried (Anthias, 1992: 115). After 1974 these cordial relations were obviously strained, but the Cypriot community in London did not 'split' as it did in Cyprus. In fact, inter-ethnic friendships and contacts in Cyprus were often sustained via family members who stayed in touch in the London diaspora (King \& Ladbury, 1982; Ladbury, 1977). At the same time, the pan-Cypriot diasporic identity in London was pulled in different directions by the emergence of a Greek business and student community (linking up with Greek Cypriots), and the arrival of substantial numbers of Turkish and Kurdish migrants (linking with Turkish Cypriots). This led to a complex and overlapping set of Greek-Cypriot-Turkish community identities expressing varying degrees of solidarity, common purpose, tension and antagonism according to the particular situation and issue of the moment (King et al., 2008).

If the Greek and Turkish Cypriot first generation retains their strongly Cypriot identity despite several decades of living in the diaspora, the picture for the second generation is much more fluid and mixed. Whilst they were less influenced than their parents by religious observation and practices such as the dowry, issues surrounding female sexual modesty were imposed on them as still very important; indeed to a greater extent, perhaps, than the fast-changing social norms of the homeland's increasingly urbanized society. This was often made evident when second-generation teenagers were taken to Cyprus for the summer holidays. In the following interview extract from recent research on the second generation who have relocated to Cyprus, 42 year-old Maya (a pseudonym) describes the eye-opening experience of visiting Cyprus as a young teenager: 


\section{J. Teerling \& R. King}

It was really weird because I was allowed so much more freedom here [in Cyprus]. I was kept on such a tight rein in [names place in UK]... I remember being 14 and coming out here... I was allowed to go to night clubs, you know, and go out and about with my cousins in Paphos [a popular tourist resort]... go to bars, go to have an icecream outside, you know, at 12 o'clock at night, have a pizza after the disco... My parents... they'd let us wander around and go off and walk on the promenade and get ogled at by all the boys... I don't know, [my parents] had a better handle on being parents here than they did in the UK.

In her 1992 book, which remains the most detailed sociological study of the Greek Cypriot diaspora in Britain, Floya Anthias describes the different 'wavelengths' of the first and the second generations. Whilst the first generation, most of whom are now quite elderly, have been largely concerned with maintaining their language, culture and traditional family values and ties, the second generation has been keen to redefine ways of being Cypriot within British society. Some early interpretations of this ambivalence diagnosed a kind of 'lost' positionality 'between two cultures' (Constantinides, 1977). This view has been critiqued, as in this contribution by a 24 year-old male to a symposium on 'The Cypriot Community in the UK: Issue of Identity', who stated that:

One interpretation of the lives Cypriot youth live in Britain, which unfortunately is a widely held belief, is that we have a confused sense of belonging. That by and large Cypriot youngsters residing in Britain lead double lives. It is suggested that this double life is split between either being Cypriot or British, that we are Cypriot with our families and in other Cypriot circles, and English when in the company of British friends at school or work. This account suggests that Cypriot youth have an acute identity problem [...]. In my view such an analysis is deeply faulty [...]. We all adapt our behaviour to suit the particular situation we are experiencing. Even within the sphere of association with Cypriots, we behave differently with our cousins and friends, than we do with our parents. The ability to alter our actions when appropriate is a valuable social skill and essential to fitting in anywhere. I feel it is not a case of falling between or torn between two cultures, but more that Cypriot youth develop a personality; a sound one, our own individual body of culture drawing from all influences (Lambrou, 1988: 13).

The point made at the very end of this quote, about the development of a new 'body of culture' open to a wide variety of influences, is an important one for an outward-looking Cypriot diasporic identity. Such a view surfaced prominently in the narratives of belonging and cultural encounter collected by Teerling (2011a) in her study of second-generation 'returnees' to Cyprus, a group of people we will say more about below.

\section{The Diaspora 'Returns'}

Most Cypriots who migrated to the UK in the early postwar decades intended to return to live in Cyprus sooner or later (Anthias, 1992). The 'return syndrome' was rather less strong for those who migrated further afield, to overseas 'settler' destinations such as Canada and Australia. Actually, return migration is the unwritten chapter in the story of Cypriot migration, since we know of no studies having ever been carried out on the return of the original migrants. 
What we have instead are brief mentions of the phenomenon, usually linked to the growing business and employment opportunities in Cyprus (Bertrand, 2004: 99; Thomson, 2006: 2), as well as our own anecdotal observations from frequent and extended field visits.

As elsewhere - for instance in Malta and the Caribbean (Gmelch, 1980; King, 1980, 2000) return migration to Cyprus is occasioned by a much more complex set of factors than the original departure as an emigrant, which was usually economically motivated. For the return, issues such as nostalgia, family circumstances (for instance the need to look after elderly parents), business ventures or the desire to semi-retire, perhaps with a hobby-job, may all come into play. Our observations suggest that all the above are relevant, but there are no systematic survey data to gauge their relative importance.

In addition, the issue of return to Cyprus is affected fundamentally by the division of the island. For many emigrants who departed (as most did) prior to 1974, especially Greek Cypriots from the north and Turkish Cypriots from the south, return to resettle in the place of departure can no longer take place. If they do return, as some have done, it can only be to the respective 'safe havens': Turkish Cypriots to the TRNC, Greek Cypriots to the ROC. However, we sense that, for those who originate from the 'wrong side' of the Green Line, the likelihood of return is much less, mainly because 'their village' does not exist as such any more.

In the absence of solid research on the return migration of the original emigrants, we broaden the notion of 'return' in two important dimensions, both of which are more consistent with a diaspora conceptualization of Cypriot migration. First, we conceive of return mobilities rather than return migration (King \& Christou, 2011), since people return for visits, holidays, extended stays, or (semi-)permanent relocation. Second, we consider the return mobilities not only of the first generation but also of the second and subsequent generations. This is what we call counter-diasporic migration (King \& Christou, 2010), since for these foreign-born generations this is not a true 'statistical' return.

Ethnographic data and life narratives collected by Teerling (2011a; 2011b) amongst secondgeneration British-born Cypriots (both Greek and Turkish) who had relocated to Cyprus reveal that their motives for 'return' are varied, yet often pragmatic. Some had employment opportunities offered to them, for instance as teachers in international schools, or as employees in the tourist sector. For others, it was more the attraction of a relaxed lifestyle, warmer climate, and a safer environment to bring up their children. The following extract, from an interview with Rowan, a 41 year-old journalist living in North Cyprus, sums up some of these rationales for return rather well:

Until we came to Cyprus [on holiday] I had no idea but as soon as we came I fell in love with the culture and the people, and my relatives, and the village, and the animals, and all this stuff; yeah, I viewed this place as some kind of paradise... I spent my whole childhood with the assumption, and the knowledge, that I would return to Cyprus [...] which is what I did [...]. This was my holy grail, you know, this where I wanted to be. I remember walking to school [in the UK] in the pouring rain, everything was grey, even the clothes you wore were grey... everything was hard and rough and wet and cold; and in my mind there was this very nice and sunny yellow and blue place where people 


\section{J. Teerling \& R. King}

were very friendly and kind, and had time for you, and I thought that everything I wanted was here...

Aysu (48 years old), also a Turkish Cypriot, focuses on the family and children aspect in her extract:

I always had this presumption that England is a bad place to raise children, which is a terrible generalization I know; it was just based on what I had suffered. So I thought that marriage and family would be a better option here in Cyprus. Another thing that I always thought - again it goes back to the 1974 thing - 'how much longer that this problem [the Cyprus conflict] continue? It's bound to be resolved soon'. So I think I also had that expectation. So I came back... I was in love, I was going to get married... I always loved Cyprus, I never stopped having this strong bond with Cyprus.

The ways in which British-born Cypriots fit into Cyprus' increasingly urbanized, pluralistic society (especially on the Greek side) are also quite varied, and there is no standard grouping into which they can be allocated in class or ethno-cultural terms. Teerling's data on this question reveal a blurring of boundaries and the creation of new 'third-cultural spaces of belonging' which incorporate many aspects both of their British upbringing and of a modernizing, cosmopolitanizing Cyprus (Teerling, 2011a); much less of the older, 'traditional' rural Cyprus of their parents (which, in any, case, hardly exists any more).

One striking element in the narratives was the unique spaces of belonging the secondgeneration 'returnees' created beyond national, ethnic and primordial cultural boundaries. These migrants tend to create and inhabit spaces in their professional, leisure and personal lives that are shared with individuals and groups whose ethnic, national, linguistic and ancestral backgrounds vary greatly. It is precisely that diversity that unites them. The privileging of such experiences of belonging over 'traditional' classifications of identity brings about a sense of unity defined by one's relations to both actual and metaphorical spaces beyond the conventional 'here and there' and 'them and us' dichotomies (Teerling, 2011a). This observation is crucial when shaping an understanding of the social and cultural fabric of Cypriot society today, and of Cyprus as a 'multi-diasporic space', as we will see in due course.

\section{The British (Post)Colonial Diaspora: Soldiers and Retirees}

Cypriot returnees are not the only migrants coming from the UK who are now residing on the island and influencing its multi-diasporic character. The island is also in the 'hinterland' of the globe-spanning British diaspora: this time a diaspora whose 'hub' is located in the UK, and in time-space terms in the hey-day of the British Empire and Commonwealth ${ }^{5}$.

Reflecting the imperial heritage, as well as other diaspora-forming processes such as settler, business and lifestyle migration, Britons are now widely spread around the world. Interestingly, they tend to refer to themselves as 'expats' rather than migrants or diasporans.

\footnotetext{
${ }^{5}$ Robin Cohen (1997) categorizes the British case as one of the classic imperial diasporas, very different from the case of Cyprus, which is a labour diaspora, although often the two are functionally linked, since labour diasporas are often directed to their (former) colonial metropoles.
} 
According to Sriskandarajah \& Drew (2006: 17, 104), Cyprus hosts 59,000 Britons living there for at least a year, plus another 6,000 who are there part-year. The aggregate figure, 65,000, places Cyprus in tenth place for Britons resident abroad ${ }^{6}$.

There is practically no literature on the British settlers and military personnel in Cyprus, apart from an unpublished, pilot-grant report and a seminar paper by Seán Damer (1996, 1997). These documents give a rather vivid picture of the British residents, most of whom live in the Paphos area in the south-west of the island. It is clear Damer had little sympathy (to put it mildly) for the people he spent six months ethnographically researching. He defines them as essentially a 'linguistic community'. Despite many years of residence in Cyprus, 'very, very few expatriates speak Greek or make any attempt to learn it'. Instead they follow the maxim that 'if you speak loudly enough, the natives will understand'. Most are retired and many are ex-service personnel who had been stationed at one of the two British sovereign base areas on the island, as well as billeted elsewhere, such as the Gulf or Singapore. The age and political profile of this population 'ensures that issues such as the Second World War, the monarchy and the Empire are alive and well'. Damer gives lots of examples of the iconography and jingoism of British imperialism within the community and its associations and meeting-points ('British' bars and pubs). He mentions photographs of military events, weapons paraphernalia, portraits of monarchs past and present, and of Winston Churchill. He makes the withering statement that this is not a group of people who understand the meaning of words like 'ethnocentrism' or 'multiculturalism' (Damer, 1997: 13-15).

Damer's work is revealing at a number of levels, first and foremost because it is the only indepth study of the predominantly retired British expat community in Cyprus. Second, it has wider significance as the forerunner of other in-depth studies of British residents and retirees elsewhere in the Mediterranean, such as southern Spain, Malta and Tuscany (King et al., 2000; O'Reilly, 2000). Thirdly, Damer's papers are remarkable for the way they explicitly expose the problematic positionality of a researcher who is ideologically about as far removed from the population under study as it is possible to be: a Marxist sociologist amongst a fervently rightwing, retired, ex-military community living in comparative isolation in a former British colonial stronghold ${ }^{7}$.

For our analysis in this paper, Damer's research is most interesting for its powerful insights into the sociological nature of the British expat community and its relationship to Cyprus as a multi-diasporic space. Although Damer does not use the term, the people he so scathingly portrays are examples of what has since come to be known as 'lifestyle migration' (Benson \& O'Reilly, 2009). Although acknowledging subtypes (economically active vs. retirees; 'residential tourists' vs. 'rural idyllists' vs. 'bourgeois bohemians'), Benson \& O'Reilly present the core definition of lifestyle migrants as 'relatively affluent individuals... moving either parttime or full-time to places that for various reasons signify, for the migrant, a better quality of life'. According to these authors, migrants justify their relocation by referencing 'the slow pace

\footnotetext{
${ }^{6}$ After Australia, Spain, USA, Canada, Ireland, New Zealand, South Africa, France and Germany. These estimates, and the listing of countries in rank order, are culled from a variety of sources.

${ }^{7}$ In what follows we quote only from the ESRC Pilot Grant Report, as this is in the public domain. We do not quote directly from the seminar paper, even though this is quite an extensive text and does not have the 'Do not quote without the author's permission' statement on its front page, because we are unsure of the paper's status. The seminar paper is much more outspoken than the grant report.
} 


\section{J. Teerling \& R. King}

of life; the relative cost of living (including cheap property prices); the climate and health benefits; a feeling of community'. These are contrasted with 'the shortcomings of home rising levels of crime and unemployment; lack of community spirit; high-pressured lifestyles; and low quality of life' (2009: 609-610).

Damer adds extra layers of interpretation to the above characterization of lifestyle migrants. According to him, his research subjects, whom he describes as 'Little Englanders', have chosen Cyprus because it is an ex-colony with a distinctly British infrastructure - English is widely spoken, cars are driven on the left, and so on. The presence of the British sovereign bases and the dominance of British tourism to Cyprus lend a continuing post-colonial atmosphere to the island. 'Thus', Damer argues, 'the expatriate can feel superior to the native Greek-Cypriots because they are at least former colonial subjects to whom they brought the Pax Britannicum' (1997: 16, his emphasis). 'The fact that there was a very ugly anti-colonial war in Cyprus in the 1950s is swept under the carpet', Damer adds ${ }^{8}$.

Finally, although he makes some sweeping generalizations, some of which are referred to above, Damer also nuances his analysis by breaking down the Paphos expatriate community into three sociological categories (1997: 18-19). The experts, numerically small, are the older, long-term residents of Cyprus, and are mostly of a senior military background. They 'know their way around', although not to the extent of speaking much Greek. 'Members of this group are elitist, look down their noses at other expatriates as parvenus, regard tourists with horror, and are prone to talk about the "Good Old Days" before mass tourism allegedly destroyed Greek-Cypriot culture'. The biggest group are the adaptors, who come closest to Benson \& O'Reilly's (2009) definition of lifestyle migrants. This group comprises people who enjoy their active lifestyle in a beautiful island which has much to offer them. They engage in walking, bird-watching, golf, swimming, amateur dramatics and charitable work; but only in the company of other 'Brits'. Finally come the whingers, who hate being in Cyprus but have 'burnt their boats' by selling their assets in Britain to fund their relocation. They complain bitterly about the rising cost of living, the declining real value of their pensions, and are the most outwardly racist in their views about 'Blacks' in Britain and Cypriots in Cyprus. They congregate exclusively in British pubs and clubs, and their lives resemble a kind of 'Eastenders-in-the-Med' soap-opera (Damer, 1997: 7).

Damer concludes (1997: 20) that the similarities within the British community are greater than the differences between the three groups, which are loose and fluid categories anyway. What unites them is their inward orientation to their own 'linguistic community' and their lack of contact, let alone integration, with Cypriot society and ways of life. This has obvious implications for our analysis of inter-diasporic relations, which we come to later in the paper.

Before we leave the British diaspora, mention should also be made of the 3,000 servicemen and women linked to the two sovereign base areas at Akrotiri near Limassol and Dhekelia near Larnaca. No empirical research is available on the lives of these military personnel, although

\footnotetext{
8 We are tempted to speculate on the motives behind Damer's choice of research subject. His 'official' explanation - that 'there had [at that time] been no published anthropological or sociological studies of British expatriates anywhere in the Mediterranean' (Damer, 1997: 1) - seems persuasive enough at face value. But surely, as an experienced sociologist, he must have seen the ideological and political clash looming.
} 
the visual impact of the settlements is clear to see from the public roads that traverse the bases. The authorities have created a 'little England' with 'English' street names and house-styles, suburban gardens, cricket pitches and sports fields which project the aesthetics of colonial power (Constantinou \& Richmond, 2005: 76). Whilst the bases can be regarded in some respects as a geographical and historical anachronism, they have enormous geo-strategic significance within the context of a highly politically unstable Eastern Mediterranean. Part of that instability is related to the production of new migration flows to Cyprus.

\section{New Immigrants: Cyprus as a Diasporic Hinterland}

Over the past 20 years, Cyprus has played host to a growing number of migrants from a wide diversity of origins. Various factors, historical, geopolitical and economic, have combined to make Cyprus a major immigration pole (for its size), strategically positioned on the southeastern periphery of Europe (and since 2004 of the EU), at the threshold of the Middle East with its onward links to Asia and Africa.

The economic factor remains a major structural pull for labour migrants, and Cyprus (minus the TRNC) holds the position as the most prosperous and dynamic economy in the eastern Mediterranean, ahead of Greece in this regard ${ }^{9}$. Curiously, part of the boom in the (Greek) Cypriot economy was related to the knock-on effects of partition and the availability of a sudden extra supply of labour in the form of displaced Greek Cypriots from the Turkishoccupied north. The tourist and service economies of the south enjoyed a period of rapid expansion, helped also by the availability of capital and businesspeople seeking refuge from the Lebanese conflict. Immigration controls were loosened during the 1990s, when Cyprus started granting a large number of temporary visas to foreign workers (Trimikliniotis \& Demetriou, 2007). Availability of these visas had to be restricted (except for EU citizens) after the accession of Cyprus to the EU in May 2004.

Geopolitical factors favouring new immigration processes were not only located within the island and in the nearby Middle East; also the collapse of the bipolar divide in Europe opened up new migrant links to Cyprus. Of key importance here were the Pontic Greeks, free after 1989 to move out of Russia and the Caucasus region, especially Georgia. They were automatically offered Greek citizenship and, as such, they were also free to onward-migrate to Cyprus, where they were granted permanent residence and the right to work. They have settled in quite large numbers (12,000 in 2004), especially in the Paphos area. As part of the longstanding Greek diaspora, they were thus able to exercise choice and advantage, and move from one part of the hinterland of the Greek diaspora to another. Although most of them had a premigration background as skilled workers, their access to the labour market in Cyprus has been mainly confined to lower-status manual jobs; men in construction and petty services, women in cleaning jobs and retail outlets. Despite, or indeed perhaps because of, their related ethnic origins to the Greek-Cypriot host population, the Pontians have been subjected to a good deal of prejudice and discrimination, including being stereotyped as trouble-makers and as adhering to 'old-fashioned' patriarchal family structures. They are labelled 'Russo-Pontians'

\footnotetext{
${ }^{9}$ Of course this dynamism has been seriously affected by the post-2008 recession and crisis in the Euro-zone. Cyprus has suffered as a result of this, but to a much lesser extent than its larger neighbour, Greece.
} 


\section{J. Teerling \& R. King}

(Rossopóntii) to emphasize their 'Russian' origins and hence their 'distance' from Greek Cypriots (Gregoriou, 2009).

Migrants have also moved to Cyprus in significant numbers from other parts of the old Eastern bloc, as well as Yugoslavia after its break-up. Cyprus has proved especially attractive to migrants from countries of the Orthodox Christian faith - Russians, Georgians, Bulgarians, Romanians and Serbs. Amongst the Russians especially, there is a wealthy business community which is quite large and well organized, with its own churches, private schools, newspapers and cultural centres. They are particularly concentrated in and around the coastal town of Limassol, with its extensive endowment of tourist hotels and entertainment facilities. The other East European communities also have their respective associational lives, but not on the scale of the Russian presence (Teerling \& King, 2011: 17).

Like the Pontians, and indeed most other migrant nationalities in Cyprus, the East European migrant communities are highly gendered with regard to their occupational niches. Aside from the business community (which also involves some women in managerial and ownership positions), less educated migrant men mainly work on construction projects, whilst women work in various service-sector occupations linked especially to the tourist market. Many Eastern European women have entered Cyprus on a special visa category (recently abolished) as 'artistes' or 'dancers' working in clubs and cabarets; and then drift, or are forced, into sex work as a more lucrative sideline or main activity. The 'entrepreneurs' of this industry (the club-owners and pimps) are mainly Greek Cypriots (Trimikliniotis \& Fulias-Suroulla, 2009: 175). The fact that these entertainment venues are not legally allowed to sell sexual services, but many in practice do, places the migrant women in a very vulnerable position, and often at the mercy of their employers, who often withhold their passports (Demetriou, 2008).

Three other world areas have been source regions for recent migration to Cyprus. Longrunning unrest in the Middle East, shifting from one country to another - Lebanon, Israel, Palestine, Iraq, Egypt, Syria - has contributed to the influx of both economic migrants and political refugees, many from affluent backgrounds, who work as managers, entrepreneurs, technicians and other qualified personnel (Trimikliniotis \& Demetriou, 2007). Lebanese and Palestinians are the largest, and longest settled Arab groups in Cyprus. Nicosia now has a wellestablished Arab community, reflected in a wide range of community centres, shops and restaurants run by Arabs. These people see themselves not so much as 'immigrants' as 'cosmopolitans' enjoying the 'mini-melting-pot' mixture of cultures and races in Nicosia (ElIssawi \& Georgiou, 2010).

The second area of migrant supply is South-East Asia, especially the Philippines, Thailand and Sri Lanka; mainly women employed as domestic helpers in private households and in the nursing and care sectors in the main cities. Asian men, the minority, tend to be employed in construction, manufacturing and, especially, agriculture. Asian workers tend to be the lowest paid and most exploited in Cyprus, but their differently gendered employment sectors and geographical distributions impact on their social and organizational lives. Asian men, many of whom reside in countryside areas, are more socially isolated and also more liable to violations in terms of work arrangements (Trimikliniotis \& Demetriou, 2005). The much larger number of female domestic and care workers, concentrated in urban areas, also have a history of 
exploitation and abuse, but their urban location has made it easier for them to become involved in self-help groups, including church-based activities.

The social and economic positioning of migrant domestic workers has been one feature of recent immigration to Cyprus which has been subject to some scholarly, policy and activist analysis (Anthias, 2000; 2006; Panayiotopolous, 2005; Spyrou, 2009; Trimikliniotis \& FuliasSuroulla, 2009). Reflecting the general phenomenon of the growth in demand for migrant domestic workers in many of the world's richer countries (Anderson, 2000), recent female migration to Cyprus is structurally related on the one hand to global divisions of female labour and on the other to the tendency of more Cypriot women becoming economically active. The lack of state nursery care and the slow transformation of gender roles within the household (Cypriot men, on the whole, are not very willing to do their share of cooking, cleaning and childcare) mean that the employment of migrant women becomes the 'solution'. However, this pushes the transformation of gendered social roles within the Cypriot household into the background, as well as creating knock-on effects on the migrant women's own gendered family and caring responsibilities (Anderson, 2000).

Thirdly, there are much smaller numbers of migrants from Africa - from the Horn of Africa and a wide variety of Sub-Saharan African countries. They are mainly refugees (or asylumseekers) and many have entered via irregular routes, some via Turkey and North Cyprus, which has its own set of migration dynamics.

\section{North Cyprus and its Migratory Characteristics}

Before 1974, as we have seen, the emigration of Greek and Turkish Cypriots proceeded more or less in parallel. The partition of the island radically changed the ethnic population distribution, creating a dualistic pattern of ethnic homogenization in the two parts of the island. Subsequently the respective migration dynamics developed in very different ways, although recent immigration has certainly been common to both 'sides'.

Three types of in-migration to the TRNC (between 1974 and 1983 known as the Turkish Federated State of Cyprus, TFSC) took place in the immediate aftermath of the setting up of this 'quasi-state'. First, around 45,000 Turkish Cypriots, originally from the southern twothirds of the island, transferred to the 'safe haven' of the north; at the same time, an estimated 142,000 Greek Cypriots fled to the south. Second, both during the Turkish military incursion into Cyprus and after, a strong army presence was deemed necessary to protect the Turkish Cypriots. There are said to be around 40,000 Turkish soldiers still in northern Cyprus, but their number is impossible to verify, not least because some have stayed on as settlers and become naturalized Turkish Cypriots after their military service. This takes us to the third type, the tens of thousands of settlers from mainland Turkey who have been brought over to bolster the population of the TFSC/TRNC and fill the vacant villages and properties left by the forcibly displaced Greek Cypriots (Navaro Yashin, 2006: 88-89). This third type of in-migrant is the most controversial and slippery to define and estimate because of its political sensitivity amidst accusations from the (Greek) Cypriot government of demographic engineering, and because it subsumes various types of immigrant and visitor under an ascribed and falsely homogenous category. The lower figures from the TRNC of 30,000 to 45,000 (given in various official 


\section{J. Teerling \& R. King}

releases) contrast markedly with claims from the south of 130,000 up to 160,000 mainland settlers (Hatay, 2007: 4, 6, 11).

The political use of demography and the 'war of numbers' over the total population resident in the TRNC, and especially the size of the controversial mainland-origin settlers, necessitates the type of detailed, forensic analysis which we have no space to deal with here. Fortunately, in two monographic papers, Mete Hatay has dealt with both issues: the special issue of the mainland settlers and their political integration (Hatay, 2005), and the more general problem of the size and composition of the TRNC population (Hatay, 2007). To try to cut a long and convoluted statistical story short, the TRNC de jure population (256,644 in 2006) is made up of the following components by citizenship (Hatay, 2007: 30): TRNC 178,031 (69.5\%), Turkish 70,525 (27.5\%), other nationalities (Bulgarian, UK, and minor others) $8,088(3.5 \%)^{10}$. However, there was substantial conferral of TRNC citizenship on the former soldiers who stayed on and early mainland settlers in the mid and late 1970s, with the result that the distribution of the 178,031 TRNC citizens by birthplace includes 147,405 Cyprus-born, 27,333 born in Turkey, 2,482 British-born and 913 Bulgaria-born (Hatay, 2007: 30). From this we can infer that the mainland-origin population in the TRNC amounts to at least 98,000 or $38 \%$ of the total $^{11}$. In addition to soldiers, ex-soldiers and settlers, other migrants from Turkey (not accorded TRNC citizenship) have arrived in more recent years in response to business, employment and educational opportunities. Especially notable in this regard is the sizeable population of Turkish students at northern Cyprus's universities (28,565 in 2006, up from 11,821 a decade earlier; Hatay, 2007: 34).

Hatay and other writers (Hatay, 2008; Hatay \& Bryant, 2008a; 2008b; Navaro Yashin, 2006) have commented on the interrelations between the various components of the TRNC population. An initial 'honeymoon period' (Hatay, 2008: 151) during which the Turkish Cypriots were immensely grateful to the Turkish soldiers for enhancing the security and geographical integrity of their Cypriot homeland, gave way to tensions between the two communities: Turkish Cypriot and Turkish. Jealousy was directed at the soldiers and mainlanders who were accorded special treatment in terms of their access to vacated Greek Cypriot housing and property. A parallel discourse of stigmatization evolved to that projected onto the 'Russian Pontians' by the Greek-Cypriots in the South. The Turkish mainlanders, who mainly came from poor regions in Anatolia and the remote south-east of Turkey, were regarded as 'backward', more 'traditional', too fervently religious and 'uneducated' in comparison to the more modern, 'civilized' and more secular Turkish Cypriots; in other words, the mainlanders were subject to an 'Orientalist' discourse (Hatay, 2008).

The tensions referred to above are also expressed at a spatial scale. Many abandoned GreekCypriot villages were settled en bloc by mainlanders, thereby setting up a duality between

\footnotetext{
${ }^{10}$ For a similar set of figures based on the de facto 2006 census see Hatay (2007: 29). Both de facto and de jure populations increased substantially over the 1996 census results - by $32 \%$ and $36 \%$ respectively. The figures for Bulgaria and the UK mostly refer to ethnic Turks (Bulgaria) or British-nationality but Turkish-Cypriot-parentage individuals (for the UK).

${ }^{11}$ It is also worth noting that the birthplace-of-parents data for the 147,405 Cyprus-born TRNC citizens includes 16,824 with both parents born in Turkey and 10,361 where one parent is Turkish-born. If the Turkish-born parents are still alive and resident in the TRNC, they will have been picked up by the census; if deceased or returned to Turkey, they leave behind another element of Turkish-mainland-heritage population.
} 
'Turkish' and 'Turkish Cypriot' villages which was reminiscent of pre-1974 Cyprus when most villages in Cyprus were either Greek Cypriot or Turkish Cypriot. Within the northern sector of Nicosia (the Green Line divides the city), the old city-centre districts, with their rundown tenements, became settled by recent, poor immigrants from Turkey and elsewhere, as the Turkish Cypriots moved out to more spacious housing beyond the old walls of the city. Within the walls, and especially close to the Green Line, shops, eating-places and coffee-houses reflect the culinary and other needs of this poorer, immigrant population. Hence the sights, sounds and scents of 'Old Nicosia' when it was a wholly Cypriot city (the jasmine blossom or the peddlers selling muhallebi, milk pudding sprinkled with rose-water) have been 'lost' to the more pungent smells of 'Middle Eastern' food (Hatay \& Bryant, 2008b).

There is a striking similarity between the Turkish Cypriot public perception of the northern part of Old Nicosia, which has now turned into a 'migrant space', occupied by people who are perceived not to care about its crumbling physical and social fabric, turning the area into a site of neglect and crime (Hatay \& Bryant, 2008a), and the views of Greek Cypriots about the southern part of the old town, which is also inhabited or used for leisure by a wide variety of migrants, and hence too has turned into a 'migrant space'. Two riders have to be made to this comparative generalization. First, there are more signs of prosperity, refurbishment and gentrification on the Greek side; and second the recent opening up of the Ledra Street barrier in the heart of Old Nicosia has been a first step in reuniting the inner city and restoring its collective, organic function, creating thereby a space of inter-communal encounter and mixing.

Other migrants also come to North Cyprus: students from various countries, especially from within the Eastern Mediterranean region but also from further afield; and female migrants working in domestic service and in the sex trade. The TRNC has developed a thriving night club industry geared to the demands of Turkish tourists and visitors, as well as some locals. Most of the women working in the clubs are hired under the guise of 'artistes' and 'dancers' from Eastern Europe. Considerable uncertainty surrounds whether they have been trafficked or not (Hatay, 2008: 80; Guven-Lisaniler et al., 2005: 80; 2008: 446). The domestic service niche is mainly filled by older women from Turkey.

Immigrants to North Cyprus face a number of problems, many of which are common to those of economic migrants everywhere. Some problems, however, are caused or exacerbated by the non-recognized international status of the TRNC and its marginal position within a divided island. The TRNC cannot sign conventions or ratify treaties, including those that protect human rights. Most international organizations cannot operate in North Cyprus, or do so only with difficulty. However, the opening up of more passage-points across the Green Line will at least facilitate movement across the divide, for those who want it (many Greek Cypriots are ideologically opposed to visiting the north, seeing travel there as a legitimation of the 'illegal act' of occupation by the Turkish authorities), and enable social, economic and even political links to develop. The extent to which such freer movement will be a step to a more concrete resolution of the decades-old 'Cyprus problem' remains still to be seen.

\section{Cyprus as a Multi-Diasporic Space}

Thus far, we have provided material to document the rapid social and demographic transformation that Cyprus has undergone over the past few decades in terms of migration. 
Nowadays, Cyprus has a large and diverse migrant population: diverse in terms of social, cultural and economic background, as well as in terms of the migrants' social and economic position in contemporary Cyprus. To recap, we have documented four major migration processes that configure Cyprus as a hub of overlapping diasporas, but also of exclusions and racisms:

- The mass emigration of Cypriots in the early postwar decades;

- The partial return of this diaspora, both first and subsequent generations, and including holiday and other visits 'home';

- The establishment of part of the imperial British diaspora on Cyprus, in military bases and in mainly retirement and lifestyle-oriented enclaves;

- The immigration of a wide diversity of mainly economic migrants in the last 20-25 years, filling niches of labour demand in various sectors of the expanding Cypriot economy.

Many of these migration waves are structured around the post-1974 partition of the island, which introduced new dynamics of mobility and immobility into what was already a complex insular migratory space. Two key migration processes have resulted, which can be added to the four listed above:

- The post-1974 population exchange: a more-or-less forced displacement of a third of the island's people: Greek Cypriots to the south, Turkish Cypriots to the north;

- The arrival and settlement of a substantial Turkish-mainland population into the TRNC.

Cyprus, then, has become, to borrow a phrase from Vertovec (2007), an island of 'superdiversity'. Very different from the super-diverse London used by Vertovec as the setting for his new migratory and social paradigm, Cyprus is in many ways a more manageable setting to study the inter-migrant, inter-ethnic encounters that result. This is the theme of the final part of the paper.

What we are interested in documenting here are the spaces of everyday encounter, and also of exclusion, of the various diasporic groups. We move away from a simple conceptualization of 'integration' or 'assimilation' into a purportedly homogenous 'host society', which also tends to view each migrant group as an isolated entity (the framework of most 'post-migration' research in large immigration countries) and instead look at pathways and settings for interaction in a host society which has itself become increasingly mixed and diversified, and has moved beyond the essentialized Greek and Turkish ethnic dualism. Our questions become the following: Who integrates (and who does not) into what? What are the sub-spaces of intermigrant encounter that make up the wider multi-diasporic space that is Cyprus? What activities take place in these sub-spaces? Who is included and who is excluded? What are the criteria for this inclusion/exclusion? Based on our recent and ongoing fieldwork, and on insights gained from the work of others, we select four examples. 


\section{Diasporic Children Encounter the 'Homeland'}

An interesting intra-diasporic encounter takes place when migrants return to the home country (usually to their home town or village) for holiday and family visits. These are occasions to refresh family and kinship bonds, to slake the thirst of nostalgia for people and places 'left behind' and also, perhaps, to 'show off' a bit by demonstrating the prosperity and worldliness that have supposedly accrued from the migration experience. Many studies of return migration to various island and other contexts around the world have confirmed these generalizations (see reviews in Gmelch, 1980; King, 2000). What has been much less studied is the impact of these return visits on the 'children of diaspora'; this is something that we have focused on in our recent research (King et al., 2009, 2011).

Almost without exception, the second-generation Cypriots we interviewed in London and those who had relocated to Cyprus as adults remembered their childhood visits to the island with unalloyed pleasure: as 'idyllic times and spaces' (King et al., 2009). These visits, which usually took place in the summer holidays, are associated with freedom, fun, hot and sunny weather; and meeting grandparents, uncles, aunts and peer-age cousins. The latter were especially important: they were their 'guides' and trusted chaperones with whom they could hang out, roam free in the village or at the seaside, and 'do stuff' that their parents would not allow them to do in Britain, as our earlier quote from Maya related. These visits were a powerful mechanism for identifying with the diasporic 'hub', appreciating the strong parts of Cypriot culture, and perhaps planting the seed of the idea that they might one day 'return' long-term to live in their parental homeland - as some have done.

The strong symbolism of the 'holiday return' is evident for all Cypriots, including the first generation, whose tough lives as labour migrants or small entrepreneurs in the UK (or elsewhere) leave them little room for leisure or to enjoy life. Floya Anthias (1992: 58) observed that many Cypriots only 'live' when they are on their annual holiday back in Cyprus. This sense of keen anticipation is also experienced by the children:

It was always a fantastic experience, because... I had aunties and uncles and cousins and they adored me. You know, I was their brother's son or their sister's son, and they'd spoil me and give me a lot of attention (Angelo, 36 years old).

The extent to which a link really exists between these childhood visits and subsequent 'pull' to move to Cyprus varies according to individual circumstance and opportunities. For some interviewees, like Rowan quoted earlier, the causal link was clear; for others it was more of a chance affair, deciding on the spur of the moment, or the receipt of a job offer. However, several adult-return interviewees noted the sharp contrast between the family-based welcome they had received when on holiday as children, and the much cooler reception they got as adults. Angelo continued his interview in a very different vein when describing his actual relocation. When he tried to see all his relatives, 'none of them showed any interest, and... that was a really big shock, so different from my experience as a child'. Theodora (28 years old) had a similar experience of exclusion when she settled in Cyprus to take a job in property development: 


\section{J. Teerling \& R. King}

Everyone in the family suddenly seemed very busy and I found out very quickly that it's one thing when you're on holiday and everyone has time for you, but another thing when you actually move over here... everyone kinda disappears.

Teerling's (2011a) research on the 'return' of British-born Cypriots to (especially Greek) Cyprus reveals how these migrants draw on the multi-diasporic character of Cyprus as a whole in order to create sub-spaces of belonging. To some extent, this can be seen partly as a result of their upbringing in multicultural or 'super-diverse' Britain, and perhaps also as a reaction to their 'passive exclusion' by their non-migrant Cypriot kin. Some 'returnees' were also highly critical of the bourgeois, consumerist mentality which they saw as having taken root in Cyprus, displacing the earlier culture of traditional values and hospitality. Instead, the new multidiasporic spaces and networks of belonging are based on common experiences and life-views, including age and generation, similar life-histories of having lived abroad, and sharing a cosmopolitan outlook. Hence we observe that the importance of common ground based on national or ethnic identity seems to be weakened, and partly replaced, by an emphasis on broader and internationally shared perspectives. These shared experiences and worldviews form the pathway to integration, or the criteria for inclusion, into this multi-diasporic space, which itself derives from the multi-diasporic character of Cyprus. This multicultural sub-space is seen best of all in Nicosia, especially in the central districts within and immediately adjacent to the old Venetian walls, as Nicholas (31 years old) relates:

Nicosia is for me like the only place [in Cyprus] where you can go and feel multicultural, especially on Sunday... You can walk by and see Bangladeshis playing cricket - or they could be Sri Lankan, I don't know... Last Sunday I went to the Nepalese New Year celebrations; that was great, I didn't realize there were so many Nepalese in Nicosia... for me that was fantastic... Then there are a lot of Chinese, we never had so many Chinese... [but]... they don't interact with society in the same way as the other cultures do. Now we get a lot of Russians, especially down in Limasol... you get a lot more English in Paphos... But for me, I like the idea of Cyprus being multicultural, I do.

\section{Intercultural Encounters in the Classroom}

A second arena that has received a considerable amount of academic and policy-and-practice attention is the role of pedagogy within the new multicultural reality of Cyprus. Our evidence here is limited to the situation in the ROC, and is drawn from a large number of studies, cited below. The ideal is a learning and socialising environment where children of diverse (including mixed) heritages interact and 'share' their diverse cultural and linguistic backgrounds. This is an idealized world: often teachers, parents, pupils and the school system itself conspire to create divisions and exclusions.

Despite the increasing diversity within Cypriot classrooms ${ }^{12}$, the myth of the homogenous, monocultural and ethnocentric (Greek) Cypriot society prevails, due to its historical

\footnotetext{
${ }^{12}$ According to the Cyprus Ministry of Education and Culture (2007), 7.3\% of the pupils entering primary schools do not speak Greek as their mother tongue. This phenomenon is highly concentrated in poor, inner-city schools, where non-indigenous pupils often constitute the majority.
} 
embeddedness within nationalist rhetoric and the educational system, and its wider cultivation by the media (Bryant, 2004). The curriculum, explicitly or implicitly, is infused with nationalistic and Christian Orthodox values, predisposing assimilation rather than multiculturalism, and leaving very little space for the recognition or celebration of diversity (Angelides et al., 2004; Panayiotopolous \& Nicolaidou, 2007; Papadakis, 2008; Trimikliniotis, 2004; Zembylas, 2010). Most teachers do not receive adequate training in multicultural education, the necessity for which has only been officially recognized recently ${ }^{13}$. Appropriate training is based on the initiatives of the schools themselves or of individual teachers (Papamichael, 2008). The main effort is geared toward language training and support for nongrecophone students, ignoring the wider issues of multicultural education and combating discrimination.

There is now a wealth of critical literature on the manifest failings of Cypriot public schools to reflect pupil diversity and tackle racism and prejudice in the classroom and in wider society. The earlier negative perceptions towards Turkish Cypriot pupils have resurfaced with the opening of the Green Line and the possibility of students from the TRNC to attend schools south of the line. Several studies indicate that Greek Cypriot youngsters' (and teachers') attitudes towards Turkish-Cypriot and other 'minority' children exhibit a range of negative feelings (such as 'dirty', 'traditional', 'unruly', and 'slow'), reflecting wider attitudes in Cypriot society (Philippou, 2005; Spyrou, 2004; Trimikliniotis, 2004; Zembylas et al., 2010). Data are now available indicating the academic under-performance of immigrant-origin children in the Cypriot public education system (Theodosiou-Zipiti et al., 2011). Teachers' prejudiced attitudes, lack of appropriate training and limited sense of responsibility towards the migrant-origin children places the latter in a multiply disadvantaged situation, creating a barrier to their academic success, sense of self-worth, and overall socio-educational inclusion (Theodosiou-Zipiti et al., 2010). A recent study of two secondary schools with significant numbers of minority students is revealing in its detailed examples of the transmission of stereotyped gendered migrant identities from the wider Cypriot society to the pupils' behaviour towards migrant-origin classmates (Gregoriou \& Christou, 2011: 37-41). Daughters of East European women were assumed to be 'easy' and 'available' by the boys in school, and were treated accordingly, to the girls' annoyance and distress ${ }^{14}$. Another striking example was the way in which the daughter of a Filipino mother was treated as a 'servant' by the other pupils who constantly asked her to fetch and carry their bags, or food from the canteen ${ }^{15}$.

Yet, some more encouraging results can also be found. The children who took part in the studies by Hadjitheodoulou-Loizidou \& Symeou (2007) and Partasi (2011) were generally

\footnotetext{
${ }^{13}$ The phenomenon of multiculturalism in Cypriot schools was first acknowledged only in 2002 in a circular sent to primary schools on 'intercultural education'. Intercultural education policy remained limited to primary schools until 2008, after which, at secondary school level, it was referred to as 'integration measures'. Both sets of measures mainly involved rectifying the 'deficiencies' of the alloglossoi (speakers of languages other than Greek), by helping them to learn Greek. This represents a powerful binary of 'othering' according to migrantorigin and language knowledge which does little to confront racism and discrimination - if anything it acts to reinforce them by creating hierarchies and categories based on national origin and language skills (Gregoriou \& Christou, 2011: 23-25; Zembylas, 2010).

${ }^{14}$ See also Skapoulli's (2009) study on the collapse of girls' national/cultural background into the rigid 'virgin vs. whore' binary.

${ }^{15}$ See also Spyrou (2009) on the 'internationalization' of the Asian domestic worker stereotype by Greek-Cypriot children in families with such workers.
} 


\section{J. Teerling \& R. King}

positive about having classmates or friends from other national or ethnic backgrounds. Both indigenous and non-indigenous students appreciated the chance to learn about other countries and cultures. They claimed to enjoy the multicultural character of their classes, but said that the language barrier could be a problem (also Panyiotopoulos \& Nicolaidou, 2007). And Papamichael's (2008) paper on Greek-Cypriot teachers' understanding of multicultural education demonstrates teachers' awareness and reflexivity on their own practices and assumptions - including the limiting fact that the intercultural activities implemented mainly belong to an 'additive approach'. Indeed, the highlighting of minority cultures in a 'celebratory' way actually reinforces the idea of the dominant culture as the 'normal' or 'standard' one - an approach which does not fundamentally challenge xenophobic ideas.

Finally, it is important to note that whilst both public (state) and private (international) schools have an increasingly multicultural character, the student bodies, and hence the pathways of integration or exclusion, are very different. The migrant pupils attending the state schools are generally the children of working-class labourers and economic migrants, whilst those attending private schools, which are fee-paying, come from more affluent backgrounds. The international schools generally have English as their main language of instruction and are oriented towards preparing students for university studies in the UK or North America. The clientele parents include wealthy local Cypriots, returned migrants, and members of the business and diplomatic communities. The atmosphere in these schools is perhaps more cosmopolitan than multicultural.

\section{The Church as a Multi-Diasporic Space}

Both the Anglican Church and the Catholic Church in Nicosia are good examples of a multidiasporic space of international encounter. Here we present participant observation notes on the Anglican Church. The Catholic Church is an equally illustrative example, with its Mexican, Filipino and Sri Lankan priests and diverse congregations of Asians, Europeans, Africans and others.

The headline of the St. Paul's Anglican Cathedral Church website reads: 'Jesus said "My house shall be a house of prayer for many nations", which is followed by a welcome note from the Canadian-born Reverend in which he states: 'We welcome all those who come through our doors [...] whether local to Nicosia, visiting us from elsewhere in Cyprus, or coming from anywhere in the whole world'.

Indeed, when attending a service or any other of the church-related activities, the diversity of the congregation and visitors is striking. Amongst others and in no particular order: Australians, South Africans, Britons, Canadians, Russians, Danes, Latvians, Lithuanians, Armenians, Ethiopians, Nigerians, Brazilians, Indians, Sri Lankans, Filipinos and Cypriots (especially 'return' migrants) are all attracted to this pretty church set in its lush garden. During the Sunday services, the Canadian minister is assisted at the altar by a Welshman, a Nigerian and a Filipino, whilst the choir is made up of Britons, Filipinos, Danes and Latvians, accompanied by a Russian organist.

Several other events take place within the ambit of the church: Saturday-morning book fairs and thrift shops in the church grounds; coffee mornings open to all; mothers-and-toddlers 
groups; and a weekly men's bowling session which, according to the St. Paul's website, provides 'an opportunity to strike a (very) few pins, down a couple of beers, and enjoy the companionship with like-minded Christian men'. Other events frequently involve food, and the diversity of the congregation is naturally reflected in the variety of dishes prepared.

The church is also popular with mixed couples, where one of the partners is Cypriot and the other is of a different Christian group. The Greek Orthodox Christian partners seem happy to attend services and other events and appreciate the inclusive nature of the Anglican community: as one Cypriot spouse of a British Anglican wife said, 'the Greek-Orthodox Church is user-unfriendly'.

The pathway of integration into the multi-diasporic space of the church community is based on 'like-mindedness' - by which is meant, we suggest, a shared desire to be part of this particular Christian community, whether based on a strong religious conviction or on interest in the 'byproducts' of this Christian institution, such as its facilities, hospitality, ethics and general sense of community. What is also striking is the wide variety of socio-economic backgrounds of its members: on a Sunday morning, the British 'expats' arrive in their luxury cars, whilst the Asian labourers and domestic cleaners, for whom this may be their only day off in the week, arrive by bus or on foot.

This heterogeneous group, in terms of ethnic, national and social class backgrounds, comes together to experience a sense of familiarity and belonging as migrants, visitors and settled residents in Cyprus. The sense of belonging ignores ethnic origin or migrant nationality, but is based instead on the shared desire to worship, experience spirituality, or just feel accepted and welcomed into a Christian community in Cyprus. In fact, as the Reverend explained, many of the church visitors are not Anglicans in their country of origin, but come to the church because it provides services and an environment 'closest to their own religion'. There is also the point, relevant to the thesis of this paper, that the small scale of the island host context fosters heterogeneity and contact between migrants of different origins, simply because the small scale of each migrant 'community' does not sustain the establishment of their own ethnic churches.

\section{Informal Spaces of Inter-Diasporic Encounter}

Given the variety of diasporic groups (including Cypriots) present in Cyprus, especially in the 'mini-metropolis' of Nicosia, there are plenty of informal spaces of mixing and encounter which are smaller in scale and more 'everyday' in nature than churches or schools, or planned holidays and returns. These include the street, the bar, the park, the beach and many more. Here we pick up two slightly more institutionalised Nicosia spaces of inter-migrant encounter which nevertheless rely on the spontaneous and the everyday for their role as multi-diasporic spaces. Although we have visited these spots, our account mainly draws on a paper by Philippou (2008).

First we focus on the somateio (social club) of the Anorthosis Famagusta football team (or soccer, in North America). The hard-core, mainly male fans of Anorthosis - a club with Greek nationalist roots whose home base (Famagusta) is now in TRNC - use the space to socialize, eat, drink and watch football. The club's Nicosia somateio is run by a Greek Cypriot and his Filipino wife, who serve Filipino food alongside the traditional grilled and spit-roasted taverna 


\section{J. Teerling \& R. King}

fare. This soon attracted the custom of the Nicosia Filipinos, who now visit the locale and also use it for some of their social events, such as weddings and christenings, and a karaoke was installed for their entertainment. Many mixed couples are also regular customers and, despite the club's nationalist roots, it is patronized by some fans from the most popular leftist football club in Cyprus, Omonia. Other regulars include 'an English man who watches English premier league matches wearing a CCCP inscribed t-shirt and a Turkish Cypriot man who has a taste for grilled lamb chops and KEO [a local beer] and enjoys watching Anorthosis with his GreekCypriot friend' (Philippou, 2008: 192). Hence the pathway into this informal multi-diasporic integrated space seems to be commonalities of (male) interest in football, food and drink, the big flat-screen TV and working-class background, rather than ethnicity, nationality or religion.

The second example, also delightfully described by Philippou (2008), is set within the small informal space of a Halal butcher's shop and its adjacent restaurant, where a wide range of low-price dishes - popular amongst Muslim migrants and others, including local Cypriots - are served. With clientele from a variety of Arab countries and the Indian Subcontinent, the establishment provides for an eclectic experience of Lebanese tea and nargileh (a tobacco water pipe popular across the Near and Middle East), alongside South Asian curries and casseroles, which can be consumed in front of a large-screen TV, against a background of Arabic adornments. In this instance, the pathways into this particular multi-diasporic space are based on certain shared needs - tasty and cheap Halal food - rather than ethnicity.

\section{Conclusion}

The above four examples of inter-diasporic encounters based on holidays and returns, school settings, church spaces, and football and food by no means exhaust the spaces and types of encounter to be observed on this demographically and diasporically complex island. We have said little about what goes on in the North; or about the self-imposed enclaved lives of the British retirees; or about the highly personal and claustrophobic encounters which take place within private households between Cypriot families and their Sri Lankan or Filipino maids. We have also set aside the geographic inter-diasporic space of the 'dead zone' along the Green Line, patrolled by the 'blue berets' of the UN peace-keeping personnel (Papadakis, 2005); themselves constituting a multinational group. There remains plenty of scope for further research into these and other spaces of encounter, belonging and exclusion amongst the various diasporic and mobile groups.

Such future research should, firstly, and to repeat what we have said in the introduction, move beyond the notions of assimilation, ethnic enclaves, and disjunctures between immigrants and a falsely homogenized host society. It should, secondly, investigate spaces of belonging within alternative, 'post-identity' spatial settings, which are particularly characteristic of complex and culturally diverse societies. But it should go even further and, thirdly, investigate how such spaces of belonging draw on, overlap, and co-exist alongside more 'traditional' local communities. So, following Antonsich (2010: 653):

[R]ather than envisioning a passage from territorialized to de-territorialized forms of belonging, as some scholars have too simplistically advocated, it seems more plausible to think of contemporary societies as characterized by the co-presence of a plurality of forms of belonging. 
There is one more residual dimension of the ethno-diasporic story of Cyprus to be considered. This is the way in which migrants and expats interact with (or do not) the historic Greek and Turkish ethnic duopoly; and here we go back to the 1960 constitution. This constitution forced the existing (numerically small but ethnically very self-aware) minorities of Cyprus Armenians, Latins, Maronites and Roma - to opt for membership of one or other of the dominant communities. As Constantinou (2007: 248) pointed out, 'the most disturbing thing about being Cypriot is that one can only be a Greek or Turkish Cypriot'; being solely and simply a Cypriot is a 'constitutional impossibility'. This is despite research which shows that Greek or Turkish Cypriots increasingly affirm a Cypriot self-identity rather than an ethnicallyhyphenated one (Hadjipavlou, 2003). The constitutional impasse naturally affects the 150,000 or so immigrants who have arrived on the island in the past few decades. They tend to be excluded from discussions of evolving Cypriot identity and dismissed as 'non-Cypriot communities' or even as 'non-communities' (Philippou, 2008) despite their numerical weight and significant contribution to the economy and to the evolving social and cultural fabric of the island.

\section{References}

Adey, P. (2010) Mobility, London, Routledge.

Anderson, B. (2000) Doing the Dirty Work, London, Zed Books.

Angelides, P., Stylianou, T. \& Leigh, J. (2004) 'Multicultural Education in Cyprus: A Pot of Multicultural Assimilation?’ Intercultural Education, Vol. 15, No. 4, pp. 307-315.

Anthias, F. (1992) Ethnicity, Class, Gender and Migration: Greek-Cypriots in Britain, Avebury, Aldershot.

Anthias, F. (2000) 'Metaphors of Home: Gendering New Migrations to Southern Europe', in F. Anthias \& G. Lazaridis (eds.) Gender and Migration in Southern Europe: Women on the Move, Oxford, Berg, pp. 15-47.

Anthias, F. (2006) 'Researching Society and Culture in Cyprus: Displacements, Hybridities, and Dialogical Frameworks', in Y. Papadakis, N. Peristianis \& G. Welz (eds.) Divided Cyprus: Modernity, History, and an Island in Conflict, Bloomington IN, Indiana University Press, pp. 176-193.

Antonsich, M. (2010) 'Searching for Belonging: An Analytical Framework', Geography Compass, Vol. 4, No. 6, pp. 644-659.

Benson, M. \& O'Reilly, K. (2009) 'Migration and the Search for a Better Way of Life: A Critical Exploration of Lifestyle Migration', Sociological Review, Vol. 57, No. 4, pp. 608-625.

Bertrand, G. (2004) 'Cypriots in Britain: Diaspora(s) Committed to Peace?' Turkish Studies, Vol. 5, No. 2, pp. 93-110.

Brah, A. (1996) Cartographies of Diaspora, London, Routledge.

Bryant, R. (2004) Imagining the Modern: The Cultures of Nationalism in Cyprus, London, I.B. Tauris.

Cohen, R. (1997) Global Diasporas: An Introduction, London, UCL Press. 
Connell, J. (2007) 'Island Migration', G. Baldacchino (ed.) A World of Islands: An Island Studies Reader, Charlottetown, Canada, Institute of Island Studies, University of Prince Edward Island, pp. 455-481.

Connell, J. \& King, R. (1999) 'Island Migration in a Changing World', in R. King \& J. Connell (eds.) Small Worlds, Global Lives: Islands and Migration, London, Pinter, pp. 1-26.

Constantinides, P. (1977) 'The Greek Cypriots: Factors in the Maintenance of Ethnic Identity', in J. L. Watson (ed.) Between Two Cultures: Migrants and Minorities in Britain, Oxford, Basil Blackwell, pp. 269-300.

Constantinou, C. M. (1990) Economic Factors and Political Upheaval as Determinants of International Migration: The Case of Cyprus, Nicosia, Cyprus Research Centre.

Constantinou, C. M. (2007) 'Aporias of Identity: Bicommunalism, Hybridity and the Cyprus Problem', Cooperation and Conflict, Vol. 42, No. 3, pp. 247-270.

Constantinou, C. \& Richmond, O. (2005) 'The Long Mile of Empire: Power, Legitimation and the UK Bases in Cyprus', Mediterranean Politics, Vol. 10, No. 1, pp. 65-84.

Cyprus Ministry of Education and Culture (2007) Annual Report 2007. Nicosia: Ministry of Education and Culture.

Damer, S. (1996) 'True Brits? British Expatriates in Paphos, Cyprus'. Seminar paper, Department of Sociology, University of Edinburgh, 24 April.

Damer, S. (1997) British Expatriates: The Parameters of a Community. End of award report to ESRC Grant number R000221644.

Demetriou, O. (2008) Migrant Cities Research: Nicosia South, Nicosia, PRIO.

El-Issawi, F. \& Georgiou, M. (2010) 'Media Use at the Crossroads: Nicosia', Journalism, Vol. 11, No. 6, pp. 758-763.

Gmelch, G.M. (1980) 'Return Migration', Annual Review of Anthropology, Vol. 9, pp.135-159.

Gregoriou, Z. \& Christou, G (2011) 'The Dubious Gift/Debt of Integration: Patriarchal Regimes, Ethnicity and Sexuality in the School Lives of Migrant Girls in Cyprus', in J. Christodolou (ed.) Young Migrant Women in Secondary Education, Nicosia, University of Nicosia Press, pp. 21-57.

Gregoriou, Z. (2009) Policy Analysis Report: Migration in Cyprus, Nicosia, University of Cyprus.

Güven-Lisaniler, F., Rodríguez, L. \& Uğural, S. (2005) 'Migrant Sex Workers and State Regulation in North Cyprus', Women's Studies International Forum, Vol. 28, No. 1, pp. 79-91.

Güven-Lisaniler, F., Uğural, S. and Rodríguez, L. (2008) 'Human Rights of Migrant Women Workers in Janitorial Services and Night Clubs: The Case of North Cyprus', International Journal of Social Economics, Vol. 35, No. 6, pp. 435-448.

Hadjipavlou, M. (2003) 'Inter-Ethnic Stereotypes, Neighbourliness, Separation: Paradoxes and Challenges in Cyprus', Journal of Mediterranean Studies, Vol. 13, No. 2, pp. 281-318. 
Hadjitheodoulou-Loizidou, P. \& Symeou, L. (2007) 'Promoting Closer Ties and Cooperation Between School, Family and Community in the Framework of Intercultural Education', Journal about Parents in Education, Vol. 1, No. 1, pp. 63-72.

Hatay, M. (2007) Is the Turkish-Cypriot Population Shrinking? Nicosia/Oslo, PRIO Cyprus Centre Report 2/2007.

Hatay, M. (2008) 'The Problem of Pigeons: Orientalism, Xenophobia and a Rhetoric of the "Local" in North Cyprus. Cyprus Review, Vol. 20, No. 2, pp. 144-172.

Hatay, M. and Bryant, R. (2008a) Migrant Cities Research: Nicosia North, Nicosia, PRIO.

Hatay, M. and Bryant, R. (2008b) 'The Jasmine Scent of Nicosia: Of Returns, Revolutions, and the Longing for Forbidden Pasts', Modern Greek Studies, Vol. 26, No. 2, pp 423-449.

Khadria, B. (2011) 'Globalization and Migration in the South', Paper presented at a plenary session, $16^{\text {th }}$ Metropolis Conference 'Migration Futures', Ponta Delgada, Azores, 12-16 September.

King, R. (1980) The Maltese Migration Cycle: Perspectives on Return, Oxford, Oxford Polytechnic Discussion Papers in Geography, No. 8.

King, R. (2000) 'Generalizations from the History of Return Migration', in B. Ghosh (ed.) Return Migration: Journey of Hope and Despair? Geneva, UN/IOM, pp. 7-55.

King, R. (2009) 'Geography, Islands and Migration in an Era of Global Mobility', Island Studies Journal, Vol. 4, No. 1, pp. 53-84.

King, R. \& Christou, A. (2010) 'Cultural Geographies of Counter-Diasporic Migration: Perspectives from the Study of Second-Generation "Returnees" to Greece', Population, Space and Place, Vol. 16, No. 2, pp.103-119.

King, R. \& Christou, A. (2011) 'Of Counter-Diaspora and Reverse Transnationalism: "Return" Mobilities to and from the Ancestral Homeland', Mobilities, Vol. 6, No. 4, pp. 451-466.

King, R. \& Kolodny, E. (2001) 'Marginal or Nodal? Towards a Geography of Mediterranean Islands' in King, R., P. De Mas \& J. Mansvelt Beck (eds.) Geography, Environment and Development in the Mediterranean, Brighton, Sussex Academic Press, pp. 237-260.

King, R. \& Ladbury, S. (1982) 'The Cultural Construction of Political Reality: Greek and Turkish Cyprus since 1974', Anthropological Quarterly, Vol. 55, No. 1, pp. 1-16.

King, R. \& Thomson, M. (2008) 'The Southern European Model of Immigration: Do the Cases of Malta, Cyprus and Slovenia Fit?' Journal of Southern Europe and the Balkans, Vol. 10, No. 3, pp. 265-291.

King, R., Christou, A. \& Teerling, J. (2009) Idyllic Times and Spaces? Memories of Childhood Visits to the Parental Homeland by Second-Generation Greeks and Cypriots, Brighton, University of Sussex, Sussex Centre for Migration Research Working Paper No. 56.

King, R., Christou, A. \& Teerling, J. (2011) “We Took a Bath with the Chickens”: Memories of Childhood Visits to the Homeland by Second-Generation Greek and Greek Cypriot "Returnees". Global Networks, Vol. 11, No. 1, pp. 1-23. 
King, R., Fielding, A. \& Black, R. (1997) 'The International Migration Turnaround in Southern Europe', in R. King \& R. Black (eds.) Southern Europe and the New Immigrations, Brighton, Sussex Academic Press, pp. 1-25.

King, R., Thomson, M., Mai, N., \& Keles, Y. (2008) 'Turks in the UK: Problems of Definition and the Partial Relevance of Policy', Journal of Immigrant and Refugee Studies, Vol. 6, No. 3, pp. 423-434.

King, R., Warnes, T. \& Williams, A.M. (2000) Sunset Lives: British Retirement Migration to the Mediterranean, Oxford, Berg.

Ladbury, S. (1977) 'The Turkish Cypriots: Ethnic Relations in London and Cyprus', in J. L. Watson (ed.) Between Two Cultures: Migrants and Minorities in Britain, Oxford, Basil Blackwell, pp. 301-331.

Lambrou, L. (1988) 'Contributions from Second and Third Generations', in J. Charalambos, G. Hajifanis \& L. Kilonis (eds.) The Cypriot Community of the UK: Issues of Identity, London, PNL Press, pp. 13-16.

Lowenthal, D. \& Comitas L. (1962) 'Emigration and Depopulation: Some Neglected Aspects of Population Geography’, Geographical Review, Vol. 52, No. 2, pp. 195-210.

Navaro-Yashin, Y. (2008) 'De-Ethnicizing the Ethnography of Cyprus: Political and Social Conflict between Turkish Cypriots and Settlers from Turkey', in Y. Papadakis, N. Peristianis \& G. Welz (eds.) Divided Cyprus: Modernity, History, and an Island in Conflict. Bloomington IN: University of Indiana Press, pp. 84-99.

O'Reilly, K. (2000) The British on the Costa del Sol, London, Routledge.

Oakley, R. (1979) 'Family, Kinship and Patronage: the Cypriot Migration to Britain', in V. S. Khan (ed.) Minority Families in Britain: Support and Stress, London, Macmillan, pp. 13-34.

Panayiotopoulos, C. \& Nicolaidou, M. (2007) 'At a Crossroads of Civilizations: Multicultural Educational Provision in Cyprus through the Lens of a Case Study', Intercultural Education, Vol, 18, No. 1, pp. 65-79.

Panayiotopoulos, P. (2005) 'Globalization of Care: Filipina Domestic Workers and Care for the Elderly in Cyprus', Capital \& Class, Vol. 29, No. 2, pp. 99-134.

Papadakis, Y. (1998) 'Greek Cypriot Narratives of History and Collective Identity: Nationalism as a Contested Process', American Ethnologist, Vol. 25, No. 2, pp. 149-165.

Papadakis, Y. (2005) Echoes from the Dead Zone: Across the Cyprus Divide, London, I.B. Tauris.

Papadakis, Y. (2008) History Education in Divided Cyprus: A Comparison of Greek Cypriot and Turkish Cypriot Schoolbooks on the History of Cyprus, Oslo, International Peace Research Institute.

Papadakis, Y., Peristianis, N. \& Welz, G. (eds) (2006) Divided Cyprus: Modernity, History and an Island in Conflict, Bloomington IN, Indiana University Press.

Papamichael, M. (2008) 'Greek-Cypriot Teachers' Understanding of Intercultural Education in an Increasingly Diverse Society', Cyprus Review, Vol. 20, No. 2, pp. 51-78. 
Papapavlou, A. \& Pavlou, P. (2001) 'The Interplay of Language Use and Language Maintenance and the Cultural Identity of Greek Cypriots in the UK', International Journal of Applied Linguistics, Vol. 11, No. 1, pp. 92-113.

Partasi, E. (2011) 'Experiencing Multiculturalism in Greek-Cypriot Primary Schools', Compare: A Journal of Comparative and International Education, Vol. 41, No. 3, pp. 371-386.

Patrick, R.A. (1976) Political Geography of the Cyprus Conflict 1963-1971, Waterloo ON, University of Waterloo, Department of Geography.

Philippou, S. (2005) 'Constructing National and European Identities: the Case of GreekCypriot Pupils', Educational Studies, Vol. 31, No. 3, pp. 293-315.

Philippou, N. (2008) 'Migrants, Social Space and Visibility', Cyprus Review, Vol. 20, No. 2, pp. 189-196.

Robins, K. \& Aksoy, A. (2001) 'From Spaces of Identity to Mental Spaces: Lessons from Turkish-Cypriot Cultural Experience in Britain', Journal of Ethnic and Migration Studies, Vol. 27, No. 4, pp. 685-711.

Sert, D. (2007) 'Domestic Politics in Cyprus: Grounds for Migrant Voices', Journal of Mediterranean Studies, Vol. 17, No. 2, pp. 355-382.

Skapoulli, E. (2009) 'Transforming the Label of "Whore": Teenage Girls' Negotiation of Local and Global Gender Ideologies in Cyprus', Pragmatics, Vol. 19, No. 1, pp. 85-101.

Spyrou, S. (2004) Greek Cypriot Children's Knowledge about, Perceptions of, and Attitudes towards Foreigners in Cyprus, Nicosia, United Nations Development Program.

Spyrou, S. (2009) 'Between Intimacy and Intolerance: Greek Cypriot Children's Encounters with Asian Domestic Workers', Childhood, Vol. 16, No. 2, pp. 155-173.

Sriskandarajah, D. \& Drew, C. (2006) Brits Abroad, London, IPPR.

Teerling, J. \& King, R. (2011) Cyprus as a Multi-Diasporic Space, Brighton, University of Sussex, Sussex Centre of Migration Research Working Paper No. 67.

Teerling, J. (2011a) 'The Development of New "Third-Cultural Spaces of Belonging": BritishBorn "Return" Migrants in Cyprus', Journal of Ethnic and Migration Studies, Vol. 37, No. 7, pp. 1079-1099.

Teerling, J. (2011b) 'The "Return” of British-Born Turkish Cypriots to Cyprus: Narratives of a Fractured Homeland', Journal of Mediterranean Studies, Vol. 20, No. 2, pp. 315-341.

Theodosiou-Zipiti, G., West, M. \& Lamprianou, I. (2011) 'Attainment of Ethnic Minority Secondary School Students in Cyprus', Cyprus Review, Vol. 23, No. 1, pp. 123-144.

Theodosiou-Zipiti, G., West, M. \& Muijs, D. (2010) 'Factors Affecting Ethnic Minority Students' Attainment in Secondary Schools in Cyprus: A Focus Group Study', Intercultural Education, Vol. 21, No. 5, pp. 483-489.

Thomson, M. (2006) Migrants on the Edge of Europe: Perspectives from Malta, Cyprus and Slovenia, Brighton, University of Sussex, Sussex Centre of Migration Research Working Paper No. 35 . 
Trimikliniotis, N. (2004) 'Mapping Discriminatory Landscapes in Cyprus: Ethnic Discrimination in a Divided Educational System', Cyprus Review, Vol. 16, No. 1, pp. 53-85.

Trimikliniotis, N. (2008) 'Rethinking Migration, Discrimination and Multiculturalism in a Post-Tourist Society', Cyprus Review, Vol. 20, No. 2, pp. 13-16.

Trimikliniotis, N. \& Demetriou, C. (2005) Active Civic Participation of Immigrants in Cyprus, Oldenburg, Carl von Ossietzky Universität Oldenburg.

Trimikliniotis, N. \& Demetriou, C. (2007) 'Cyprus', in A. Triandafyllidou \& R. Gropas (eds.) European Immigration: A Sourcebook, Aldershot, Ashgate, pp. 45-58.

Trimikliniotis, N. \& Fulias-Suroulla, M. (2009) 'New Female Related Migration and Integration Related Politics in Cyprus', in M. Kontos \& K. Slany (eds.) The New Female Migration in European Societies: A State of the Art, Krakow, Jagiellonian University Press, pp. 166-185.

van Nimwegen, N. \& van der Erf, R. (2010) 'Europe at the Crossroads: Demographic Challenges and International Migration'. Journal of Ethnic and Migration Studies, Vol. 36, No. 9, pp. 1359-1379.

Vertovec, S. (2007) 'Super-diversity and its Implications', Ethnic and Racial Studies, Vol. 30, No. 6, pp. 1024-1054.

World Bank (2011) Migration and Remittances Factbook 2011, Washington DC, World Bank.

Zembylas, M. (2010) 'Critical Discourse Analysis of Educational Policy of Multiculturalism and Intercultural Education Policy in the Republic of Cyprus'. Cyprus Review, Vol. 22, No. 1, pp. 39-59.

Zembylas, M., Michaelidou, A. \& Afantintou-Lambrianou, T. (2010) 'Greek Cypriot Adolescent Attitudes towards Immigrants and "Enemy-Others" in the Context of an Ethnic Conflict'. Mediterranean Journal of Educational Studies, Vol. 15, No. 1, pp. 5-39. 